\title{
Eco-Diversity of Edible Insects of Nigeria and Its Impact on Food Security
}

\author{
Adeoye, Olubusola Temitope (Corresponding author) \\ Department of Forest Conservation and Protection
}

Forestry Research Institute of Nigeria, Jericho-Hills Ibadan. P.M.B 5054, Oyo State, Nigeria

Tel: 234-803-881-2193 E-mail: olubusolacrown@yahoo.com

\begin{abstract}
Oyelowo, Oyetayo Job
Department of Forest Conservation and Protection
\end{abstract}

Forestry Research Institute of Nigeria, Jericho-Hills Ibadan. P.M.B 5054, Oyo State, Nigeria

Tel: 234-813-400-7521Ｅ-mail: tayooyelowo@yahoo.com

\begin{abstract}
Adebisi- Fagbohungbe, Tola Abiodun
Department of Forest Conservation and Protection

Forestry Research Institute of Nigeria, Jericho-Hills Ibadan. P.M.B 5054, Oyo State, Nigeria

Tel: 234-806-621-1073 E-mail: tolaafolarin@yahoo.com
\end{abstract}

\author{
Akinyemi, Olukayode Dare \\ Department of Forest Conservation and Protection
}

Forestry Research Institute of Nigeria, Jericho-Hills Ibadan. P.M.B 5054, Oyo State, Nigeria Tel: 234-703-826-2669 E-mail: olukayodeakinyemi2007@yahoo.com

Received: June 12, 2014 Accepted: June 26, 2014

doi:10.5296/jbls.v5i2.6109 URL: http://dx.doi.org/10.5296/jbls.v5i2.6109

\begin{abstract}
Inspite of the strong aversion shown to Entomophagy (consumption of edible insects) due to
\end{abstract}


civilization, insects have played an important part in the history of human nutrition in Africa, Australia, Asia and the Americas. Hundreds of species have been used as human food. Globally, about 14 insect orders contain one or more species of edible insects. Africa is one of the leading continents that consume insects as food. In Africa, insects form part of the traditional diets of millions of people and are also used as feed for their farm animals. Nowadays, Entomophagy is a major entomological research interest with focus on its future prospect for food and feed security. Nigeria, the focus of this study is very rich in forest edible insects due to its marked ecological and climatic diversity. Some of the popular edible insects are grasshoppers, caterpillars, beetle grubs and adults, winged termites, bee, wasp and ant brood as well as winged ants, cicadas, and a variety of aquatic insects. Despite their importance as food, biodiversity and conservation efforts have focused mainly on other groups of animals, ignoring the vast world of insects. Therefore, there is a compelling need to collect data on the diversity and conservation of edible insects in Africa, and to make this information available to all interested parties. This study provides information on the list and distribution of these edible insects in Nigeria, their harvesting, processing and preservation techniques, their seasonality, nutritional value and the potential for expanding the market.

Keywords: Edible Insects, Entomophagy, Nutrition, Diversity, Food security

\section{Introduction}

Entomophagy is the term used to describe the process of eating insects as a food source. It can be divided into two categories: insects used as nutrients source and others as condiments. Insects have played an important part in the history of human nutrition in Africa, Australia, Asia and the Americas. Hundreds of species have been used as human food. Some of the more important groups include grasshoppers, caterpillars, beetle grubs and (sometimes) adults, winged termites (some of which are very large in the tropics), bee, wasp and ant brood (larvae and pupae) as well as winged ants, cicadas, and a variety of aquatic insects. Ordinarily, insects are not used as emergency food to ward off starvation, but are included as a normal part of the diet throughout the year or when seasonally available.

Worldwide, over 1,400 insect species are reportedly eaten as human food. Most are harvested from natural forests. But, while insects account for the greatest amount of biodiversity in forests, they are the least studied of all fauna. Indeed, as many insects cause massive damage and mortality to valuable commercial trees, virtually all insects are considered undesirable pests by many forest managers. Several investigations have shown that, in addition to their fundamental contribution for pollen dissemination, insects may contribute significantly to livelihoods in both rural and urban areas (Stack et al., 2003). Considering Forest insects as food helps in manipulating forest vegetation or harvest practices to increase, maximize, or sustain insect populations. Eating insects puts less strain on the environment because cultivating insects requires forests to be preserved rather than felled.

FAO (1995) notes that insects are also important Non Wood Forest Products that poor people gather, particularly women and children. Insects are a popular food in many cultures all over the world, be it as an occasional delicacy or as a replacement food in times of shortages, droughts, floods or war. Insects and meat play the same role in the human body. As food, 
caterpillars are regulars in the village but meat is a stranger. Insects can be a good source of not only protein, but also vitamins, minerals and fats. Many insects contain abundant stores of lysine, an amino acid deficient in the diets of many people who depend heavily on grain. Further, insects generally have higher food conversion efficiency than most traditional meats and reproduce at a faster rate than beef. Protein production for human consumption would be more effective and consume fewer resources than animal protein. This makes insect meat more ecological than vertebrate meat.

According to Banjo et al. (2006) the consumption of non-toxic insects therefore, should be encouraged. Insects are traditional foods in most cultures, playing an important role in human nutrition and have much nutrient to offer. They can be reared for their high nutritional qualities and sold to the populace that regards them as delicacies. The potential of insects needs to be more seriously considered in food security and poverty alleviation strategies in Sub-Saharan Africa (De Foliart, 1992). Their impact on tree health and on the forest ecosystem in general is also significant enough to yield a wide range of forest management options to address both local food needs and forest ecosystem health and productivity.

Available information suggests that nearly 1700 insect species are reported to be used as human food (Ramos- Elorduy, 2005). While 30 species or more of edible insects are used by indigenous populations in many developing countries as food. DeFoliart (1989, 1990, 2002) reported that scores of species of edible insects are prominent items of commerce in the town and village markets of Africa, tropical and semi- tropical regions of the world.

There is an urgent need to assess insect biodiversity as a whole and the role of ethno-entomophagy in particular in conserving this valuable natural resource and the local traditional knowledge for posterity. This paper therefore provides insights on commonly eaten forest insects of Nigeria, their time of availability, market distribution, nutritional value, together with other evidence from the literature research on ethno-entomophagy in Nigeria with the aim of promoting the contribution of edible forest insects to food security and forest conservation.

\subsection{The Study Areas}

The survey was carried out in Lagos, Ekiti and Benue State in Nigeria. This area is characterized by a tropical climate and has three distinct vegetation belts, namely: Mangrove, High Forest and Derived Savannah respectively. The States chosen for the study has marked ecological diversity and climatic contrast which makes them to be endowed with abundant edible forest insects and commercial edible insect's trade are also prominent in the States.

\subsubsection{Research Methods}

The information presented here was collected by questionnaire, oral interview of edible insect consumers and marketers, reviewing the literature of the works scientists have done on edible insects in Nigeria. Local libraries and the internet were also used as sources of information.

\section{Result and Discussion}

Nigeria is a country in West Africa with vast ecological and geographic diversity. There are two 
major climatic seasons, namely: Rainy (Wet) and Dry Season. This marked feature makes it to be abundant in Forest and luxuriant green vegetation especially for those in South west and South east Nigeria. This further makes their edible insect population status to be high.

Table 1. Ecological zones and locations of the study sites

\begin{tabular}{|l|l|l|l|l|l|l|}
\hline $\begin{array}{l}\text { Ecological } \\
\text { Zones }\end{array}$ & $\begin{array}{l}\text { Location in } \\
\text { Nigeria }\end{array}$ & State & $\begin{array}{l}\text { Longitude \& } \\
\text { Latitude }\end{array}$ & $\begin{array}{l}\text { Average } \\
\text { Temperature }\end{array}$ & $\begin{array}{l}\text { Land Area } \\
\begin{array}{l}\text { Altitude } \\
\text { (above sea } \\
\text { leve) }\end{array}\end{array}$ \\
\hline Mangrove & South West & Lagos & $\underline{6^{\circ} 35^{\prime} \mathrm{N} 3^{\circ} 45^{\prime} \mathrm{E}}$ & $\begin{array}{l}22.66^{\circ} \mathrm{C}- \\
30.72^{\circ} \mathrm{C}\end{array}$ & $3,474 \mathrm{~km}^{2}$ & $144 \mathrm{~m}$ \\
\hline High Forest & South West & Ekiti & $\begin{array}{l}7^{\circ} 37^{\prime} 16 \mathrm{~N} \\
5^{\circ} 13^{\prime} 17 \mathrm{E}\end{array}$ & $21^{\circ} \mathrm{C}-28^{\circ} \mathrm{C}$ & $5887.890 \mathrm{~km}^{2}$ & $455 \mathrm{~m}$ \\
\hline $\begin{array}{l}\text { Derived } \\
\text { Savannah }\end{array}$ & $\begin{array}{l}\text { South } \\
\text { East/North } \\
\text { East }\end{array}$ & Benue & $\begin{array}{l}7^{\circ} 20^{\prime} \mathrm{N} \\
8^{\circ} 45^{\prime} \mathrm{E}\end{array}$ & $21^{\circ} \mathrm{C}-32^{\circ} \mathrm{C}$ & $34,059 \mathrm{~km}^{2}$ & $104 \mathrm{~m}$ \\
\hline
\end{tabular}

Table 1 shows the geographical zones, climate and locations of the states chosen for the study in Nigeria.

\subsection{Commonly Eaten Insects in Nigeria}

In Nigeria, many insects are edible and can be consumed to combat hunger and malnutrition. Fasoranti and Ajiboye(1993) reported the consumption of 7 edible insect species by the people of Kwara State while Agbidye et al.(2009) reported 4 commercially marketed edible forest insect in Benue State. Most of these insect species are found in the order Isoptera (termites), Lepidoptera (Moths), Orthoptera (Grasshoppers/crickets), Coleoptera (Beetles) and Hymenoptera (Bees). The list of some of them is shown in Table 2.

Table 2. Commonly eaten insects in Nigeria

\begin{tabular}{|c|c|c|c|c|c|c|}
\hline Scientific name & $\begin{array}{l}\text { English } \\
\text { name }\end{array}$ & $\begin{array}{l}\text { Local } \\
\text { name }\end{array}$ & Order & Family & Location & $\begin{array}{l}\text { Consumption } \\
\text { stage }\end{array}$ \\
\hline $\begin{array}{ll}\text { Cirina } & \text { forda } \\
\text { Westwood } & \end{array}$ & $\begin{array}{l}\text { Pallid } \\
\text { Emperor } \\
\text { moth }\end{array}$ & $\begin{array}{l}\text { Yoruba: } \\
\text { Kanni, } \\
\text { Munimuni }\end{array}$ & Lepidoptera & Saturniidae & $\begin{array}{l}\text { North Central, } \\
\text { North East, } \\
\text { South-West }\end{array}$ & Larvae \\
\hline $\begin{array}{l}\text { Bunaea alcinoe } \\
\text { Cram }\end{array}$ & $\begin{array}{l}\text { Emperor } \\
\text { moth }\end{array}$ & - & Lepidoptera & Saturniidae & $\begin{array}{l}\text { North Central, } \\
\text { North-East, } \\
\text { North-West }\end{array}$ & Larvae \\
\hline $\begin{array}{l}\text { Rhynchophorus } \\
\text { Phoenics }\end{array}$ & Palm weevil & $\begin{array}{l}\text { Yoruba: } \\
\text { Ipe, Itun }\end{array}$ & Coleoptera & Curculionidae & $\begin{array}{l}\text { South-South, } \\
\text { South-West }\end{array}$ & Larvae \\
\hline $\begin{array}{l}\text { Oryctes boas } \\
\text { Oryctes monocerus } \\
\text { Oliver }\end{array}$ & Snout beetle & $\begin{array}{l}\text { Yoruba: } \\
\text { Ogongo }\end{array}$ & Coleoptera & Scarabaeidae & $\begin{array}{l}\text { South-South, } \\
\text { South-West }\end{array}$ & Larvae \\
\hline $\begin{array}{l}\text { Analeptes } \\
\text { trifasciata }\end{array}$ & $\begin{array}{l}\text { Rhinocerus } \\
\text { beetle }\end{array}$ & Ibo: Ebe & Coleoptera & Scarabaeidae & $\begin{array}{l}\text { South-South, } \\
\text { South-West }\end{array}$ & Larvae \\
\hline Anaphe venata & Caterpillar & $\begin{array}{l}\text { Yoruba: } \\
\text { Ekuku }\end{array}$ & Lepidoptera & Notodontidae & South-West & Larvae \\
\hline $\begin{array}{l}\text { Heteroligus } \\
\text { meles Billberger }\end{array}$ & Yam beetle & - & Coleoptera & Scarabaeidae & $\begin{array}{l}\text { South-West } \\
\text { South- South } \\
\text { South- East }\end{array}$ & Adults \\
\hline Zonocerus & Grasshopper & Yoruba: & Orthoptera & Pyrgomorphidae & North Central, & Adults \\
\hline
\end{tabular}




\begin{tabular}{|c|c|c|c|c|c|c|}
\hline Variegatus, & & $\begin{array}{l}\text { Tata } \\
\text { Ibo: } \\
\text { abuzu, } \\
\text { Ukpana }\end{array}$ & & & $\begin{array}{c}\text { South- South, } \\
\text { South- West }\end{array}$ & \\
\hline $\begin{array}{l}\text { Cytacantharis } \\
\text { naeruginosus } \\
\text { unicolor }\end{array}$ & Grasshopper & $\begin{array}{l}\text { Yoruba: } \\
\text { Tata } \\
\text { Ibo: } \\
\text { abuzu, } \\
\text { Ukpana }\end{array}$ & Orthoptera & Pyrgomorphidae & $\begin{array}{l}\text { North Central, } \\
\text { South- South, } \\
\text { South- West }\end{array}$ & Adults \\
\hline Apis mellifera & Honeybee & $\begin{array}{l}\text { Yoruba: } \\
\text { Oyin }\end{array}$ & Hymenoptera & Apidae & All the nation & $\begin{array}{l}\text { All through } \\
\text { Eggs, Larvae } \\
\text { and Pupae }\end{array}$ \\
\hline $\begin{array}{l}\text { Macrotermes } \\
\text { belliscosus } \\
\text { Macrotermes } \\
\text { notalensis Haviland }\end{array}$ & Termites & $\begin{array}{l}\text { Yoruba: } \\
\text { Esunsun } \\
\text { Ibo- Aku }\end{array}$ & Isoptera & Termitidae & $\begin{array}{l}\text { North Central, } \\
\text { North-East, } \\
\text { South-West }\end{array}$ & $\begin{array}{l}\text { Winged adult, } \\
\text { queen }\end{array}$ \\
\hline $\begin{array}{l}\text { Brachytrupes } \\
\text { membranaceus } \\
\text { Drury }\end{array}$ & Cricket & $\begin{array}{l}\text { Yoruba: } \\
\text { Ire }\end{array}$ & Orthoptera & Gryllidae & $\begin{array}{l}\text { North Central, } \\
\text { South-West }\end{array}$ & Adults \\
\hline $\begin{array}{l}\text { Gryllotalpa Africana } \\
\text { P.de.B. }\end{array}$ & Mole cricket & $\begin{array}{l}\text { Yoruba: } \\
\text { Ire }\end{array}$ & Orthoptera & Gryllidae & $\begin{array}{l}\text { North Central, } \\
\text { South-West }\end{array}$ & Adults \\
\hline Nezera viridula $\mathrm{L}$ & $\begin{array}{l}\text { Green Stink } \\
\text { Bug }\end{array}$ & - & Hemiptera & Pentatomidae & North-Central & Adults \\
\hline
\end{tabular}

Source: Field Survey (2013)

Table 2 shows the inventory of commonly eaten edible insects in Nigeria with their locations, their preferred stages of consumption and their common names and scientific names.

\subsubsection{Sources and Availability}

In Nigeria, insect eaters can be found in all regions of the country (Banjo et al., 2006). In the past, indigenous insect eaters were known to reside mostly in the rural areas of the country. Some kinds of Nigeria edible insects are available all year round and can be collected in forested areas and the wild (Fasoranti and Ajiboye,1993). Although a number of insect species is available throughout the year, some can only be obtained for a short season, dependent either on weather or other natural circumstances (Adeduntan and Bada, 2004; Ashiru, 1988). Insects are often collected and consumed by local people. In the past decade, a large number of insects have become available in Nigeria for domestic consumption (Agbidye et al., 2009; Muyay, 1981). However, available insects have decreased in both quantity and in the number of species due to increased demand and decreased insect habitats (Agbidye et al., 2009). A list of seasons of availability of Nigeria edible insects in local markets is presented in Table 3.

Table 3. Characteristics and seasonal availability of some edible insects in local markets in Nigeria

\begin{tabular}{|l|l|l|l|}
\hline Scientific name & Host Plant & Local market & Season Available \\
\hline Oryctes boas & $\begin{array}{l}\text { Breeds in rotting } \\
\text { Vegetation, }\end{array}$ & $\begin{array}{l}\text { Bolowou, Opuba, Ajapa, } \\
\text { Apata in Ondo, High way } \\
\text { manure standing } \\
\text { road side in Delta, }\end{array}$ & \\
& $\begin{array}{l}\text { Most or all of the year } \\
\text { e.g. } \\
\text { coconut, oil and }\end{array}$ & & \\
\hline
\end{tabular}




\begin{tabular}{|c|c|c|c|}
\hline & Raphia palms & & \\
\hline $\begin{array}{l}\text { Rhynchophorus } \\
\text { phoenicis }\end{array}$ & $\begin{array}{l}\text { Raphia palm and } \\
\text { oil palm }\end{array}$ & $\begin{array}{l}\text { Itokin in Lagos State, south } \\
\text { of Okitipupa and the town of } \\
\text { Aiyetoro near the coast, } \\
\text { Bolowou, Opuba, Ajapa, } \\
\text { Apata in Ondo, Highway } \\
\text { roadside in Delta, Edo and } \\
\text { Bayelsa States }\end{array}$ & $\begin{array}{l}\text { A short period at the near } \\
\text { end of the } \\
\text { season(September-October) }\end{array}$ \\
\hline $\begin{array}{ll}\text { Cirina } & \text { forda } \\
\text { Vitellaria } & \\
\text { Paradoxa } & \end{array}$ & & $\begin{array}{llr}\text { North } & \text { Bank-Benue } & \text { State, } \\
\text { Bisi, Erekesan-Ado-Ekiti, } \\
\text { Tede, Saki- Oyo State, } \\
\text { kwara State }\end{array}$ & June to August \\
\hline $\begin{array}{l}\text { Zonocerus } \\
\text { Manihot esculenta } \\
\text { variegatus }\end{array}$ & $\begin{array}{l}\text { Chromoelena } \\
\text { odorata, green } \\
\text { plants in general. }\end{array}$ & $\begin{array}{l}\text { Ondo State Osele, Akoko } \\
\text { Ondo } \\
\text { (November- April). }\end{array}$ & Mainly dry season \\
\hline Bunaea alcinoe & $\begin{array}{l}\text { Parkia biglobosa, } \\
\text { Prosopis africana, } \\
\text { Khaya } \\
\text { senegalensis }\end{array}$ & Wurukum- Benue State & \\
\hline $\begin{array}{l}\text { Macrotermes } \\
\text { natalensis }\end{array}$ & Tree species & Gboko main market & $\begin{array}{l}\text { Mainly the rainy season } \\
\text { (May-October) }\end{array}$ \\
\hline $\begin{array}{l}\text { Brachytrupes } \\
\text { membranaceus }\end{array}$ & $\begin{array}{l}\text { Soil and } \\
\text { underground } \\
\text { tunnel and forest } \\
\text { trees } \\
\text { nurseries }\end{array}$ & Emere- Benue State & Most or all of the year \\
\hline Anaphe venata & $\begin{array}{l}\text { Triplochiton } \\
\text { scleroxylon }\end{array}$ & South-western Nigeria & $\begin{array}{lcc}\text { Mainly } & \text { the } & \text { rainy } \\
\text { season(July-September) }\end{array}$ \\
\hline Analeptes trifasciata & $\begin{array}{l}\text { Oil palm, Raphia } \\
\text { palm }\end{array}$ & $\begin{array}{l}\text { Western Nigeria, in Ondo, } \\
\text { Delta, Edo and Bayelsa } \\
\text { States }\end{array}$ & $\begin{array}{l}\text { A short period at the end of the rainy } \\
\text { season (September-October) }\end{array}$ \\
\hline
\end{tabular}

Source; Field Survey (2013).

Table 3 shows inventory of the commonly eaten and commercially available edible forest insects at the site of study. This list also shows the main markets where they are sold, their host plant as well as their available season.

\subsubsection{Nutritional Quality}

Insects and meat play the same role in the human body (Nkouka, 1987). As food, caterpillars are regulars in the village but meat is a stranger. Insects can be a good source of not only protein, but also vitamins, minerals and fats. Many insects contain abundant stores of lysine, an amino acid deficient in the diets of many people who depend heavily on grain (DeFoliart, 1992). Furthermore, insects generally have higher food conversion efficiency than most traditional meats and reproduce at a faster rate than beef. Protein production for human consumption would be more effective and consume fewer resources than animal protein (Capinera, 2004). This makes insect meat more ecological than vertebrate meat.

In Nigeria, many studies have been carried out on the nutritional value of some species of edible insects (Banjo et al., 2006; Ifie and Emeruwa, 2011; Ekop et al., 2010; Ashiru, 1988; Agbidye et al., 2009; Fasoranti and Ajiboye, 1993). These edible insects range from the order 
Orthoptera, Lepidoptera, Coleoptera, Hymenoptera and Isoptera. It is noteworthy that Insects are high in protein energy (Ajayi and Adedire, 2007). In terms of g/100g dry weight, Cirina forda, B. alcinoe, M. natalensis, B. membranaceus have been shown to contain $74.35 \%$, $74.34 \%, 65.62 \%, 35.06 \%$ of protein respectively (Agbidye, et al., 2009). Proximate analysis in terms of g/100g dry weight in earlier studies also shows M. natalensis, Oryctes boas, Anaphe spp and Rhynchophorus phoenicis having crude fibre content of 7.85\%, 3.40\%, $1.68-3.10 \%$ and $2.82 \%$ respectively (Agbidye, et al., 2009; Banjo et al., 2006).

Insects in general are rich in fat, particularly caterpillars, palm weevil larvae and termites. High amounts of Calcium and Phosphorus $(61.28 \mathrm{mg} / 100 \mathrm{~g}$ and $136.4 \mathrm{mg} / 100 \mathrm{~g}$ ) were found in Analeptes trifasciata. Iron, Phosphorus and Vitamin A were $27-29 \mathrm{mg} / 100 \mathrm{~g}, 136 \mathrm{mg} / 100 \mathrm{~g}$ and 2.56-2.89 $\mu \mathrm{g} / 100 \mathrm{~g}$ respectively for Macrotermes spp and $85 \mathrm{mg} / 100 \mathrm{~g}$ Iron for O.monoceros (Banjo et al., 2006; Ifie and Emeruwa, 2011). Malaisse (1997) reported that consumption of $50 \mathrm{~g}$ dried caterpillars meets the daily human requirements of riboflavin and pantothenic acid as well as $30 \%$ of the requirement of niacin. Due to the high nutritional value of insects, flour made from larvae is traditionally used to prepare a pulp given to children to counter malnutrition.

\subsubsection{Harvesting, Processing and Consumption Styles}

A wide range of insects is consumed at various stages of their life cycles (Chavunduka, 1975). For example, grubs are eaten at both the larval and pupae stages. Crickets, termites and grasshoppers are eaten at the adult stages (Banjo et al., 2006). Because many insects are only seasonally available, they are frequently conserved for later consumption. They can be cooked in various ways and served as side dishes eaten with staple food. Cooked edible insects are sold commercially at roadside food stalls as well as markets in various cities of Nigeria (Agbidye, et al., 2009). Nigerian in the rural areas have used their traditional knowledge for a long time to cook each insect species in a different way; for example deep fried, fried with spices or roasted. The characteristics of local style cooking are shown in Table 4.

Table 4. The Characteristics of Local Style Cooking.

\begin{tabular}{|l|l|l|l|l|}
\hline Insect & $\begin{array}{l}\text { Local } \\
\text { name }\end{array}$ & Harvesting style & Processing style & Local style of Cooking \\
\hline $\begin{array}{l}\text { Macrotermes } \\
\text { Spp }\end{array}$ & $\begin{array}{l}\text { Ibo-Aku } \\
\text { Esunsun }\end{array}$ & $\begin{array}{l}\text { Since the winged } \\
\text { termites are attracted } \\
\text { to electric light they } \\
\text { ar trapped in a } \\
\text { receptacle with water } \\
\text { which is placed under } \\
\text { or near the light } \\
\text { source. In rural areas, } \\
\text { they are often caught } \\
\text { at the } \\
\text { termite mound itself. }\end{array}$ & $\begin{array}{l}\text { The termites wings } \\
\text { are off. }\end{array}$ & $\begin{array}{l}\text { The wings are broken off } \\
\text { fried or roasted, over a fire } \\
\text { or hot coals or fried in a pot. }\end{array}$ \\
\hline Oryctes boas & $\begin{array}{l}\text { Yoruba- } \\
\text { Ogongo }\end{array}$ & By hand picking & $\begin{array}{l}\text { Collected larvae are } \\
\text { washed. }\end{array}$ & $\begin{array}{l}\text { The washed larvae are fried; } \\
\text { condiments added include } \\
\text { onion, } \\
\text { spices and a little salt. }\end{array}$ \\
\hline Rhynchophorus & Yoruba- & By hand picking from & The end of the & The washed larvae are fried; \\
\hline
\end{tabular}




\section{Macrothink}

Journal of Biology and Life Science

ISSN 2157-6076

2014, Vol. 5, No. 2

\begin{tabular}{|c|c|c|c|c|}
\hline Phoenicis & $\begin{array}{l}\text { Ipe Ibo- } \\
\text { Ebe }\end{array}$ & dead raphia or oil palm & $\begin{array}{l}\text { abdomen, which } \\
\text { contains the guts, is } \\
\text { removed before the } \\
\text { larvae are washed }\end{array}$ & $\begin{array}{l}\text { condiments added include } \\
\text { onion, pepper, spices and a } \\
\text { little salt. }\end{array}$ \\
\hline Cirina forda & $\begin{array}{l}\text { Yoruba- } \\
\text { kanni, } \\
\text { Munimuni }\end{array}$ & $\begin{array}{l}\text { The larvae are either } \\
\text { collected from the } \\
\text { leaves on the trees or } \\
\text { pitfall traps made } \\
\text { round the bases of } \\
\text { trees with the larvae } \\
\text { and descending larvae } \\
\text { trapped } \\
\text { and collected }\end{array}$ & $\begin{array}{l}\text { The larvae are starved } \\
\text { for a day or two to } \\
\text { eliminate the contents, } \\
\text { and boiled for two } \\
\text { hours, then sun-dried } \\
\text { on mats. }\end{array}$ & $\begin{array}{l}\text { It is cooked in a stew with } \\
\text { vegetables, } \\
\text { condiments added then } \\
\text { include onion, pepper, spices } \\
\text { and a little salt }\end{array}$ \\
\hline $\begin{array}{l}\text { Zonocerus } \\
\text { variegates }\end{array}$ & $\begin{array}{l}\text { Yoruba- } \\
\text { Tata Ibo- } \\
\text { Abuzu, } \\
\text { Ukpana }\end{array}$ & $\begin{array}{l}\text { Hand picking and use } \\
\text { of sweep net. }\end{array}$ & $\begin{array}{l}\text { Allow the } \\
\text { grasshoppers to } \\
\text { starve overnight, } \\
\text { remove the gut } \\
\text { wings, and legs. }\end{array}$ & $\begin{array}{l}\text { Roasting is the method } \\
\text { frequently used for } \\
\text { cooking. First Season it in } \\
\text { spices and then fry in } \\
\text { onions, garlic, cayenne, } \\
\text { chili pepers or soy sauce } \\
\text { may be added. }\end{array}$ \\
\hline Bunaea Alcinoe & & & $\begin{array}{l}\text { The larvae are starved } \\
\text { for a day or two to } \\
\text { eliminate the gut } \\
\text { contents, and then } \\
\text { boiled for two hours, } \\
\text { then sun-dried on } \\
\text { mats. }\end{array}$ & $\begin{array}{l}\text { It is cooked in a stew with } \\
\text { vegetables, condiments } \\
\text { added include onion, pepper, } \\
\text { spices and a little salt }\end{array}$ \\
\hline $\begin{array}{l}\text { Brachytrupes } \\
\text { membranaceus }\end{array}$ & Yoruba- Ire & $\begin{array}{l}\text { Crickets are collected } \\
\text { from soil tunnels } \\
\text { which they build }\end{array}$ & $\begin{array}{l}\text { The crickets are } \\
\text { roasted over a fire or } \\
\text { hot coals. }\end{array}$ & $\begin{array}{l}\text { They turn a golden color } \\
\text { when roasted. The guts } \\
\text { are removed before } \\
\text { eating. }\end{array}$ \\
\hline Anaphe venata & $\begin{array}{l}\text { Yoruba- } \\
\text { Ekuku }\end{array}$ & & $\begin{array}{l}\text { The larvae are starved } \\
\text { for a day or two to } \\
\text { eliminate the gut } \\
\text { contents, and then } \\
\text { boiled for two hours, } \\
\text { then sun-dried on } \\
\text { mats. }\end{array}$ & $\begin{array}{l}\text { It is cooked in a stew with } \\
\text { vegetables, condiments } \\
\text { added include onion, pepper, } \\
\text { spices and a little salt }\end{array}$ \\
\hline
\end{tabular}

Source; Field Survey (2013)

Table 4 shows the characteristic ways of harvesting, processing and cooking styles for the insects found during the course of the study.

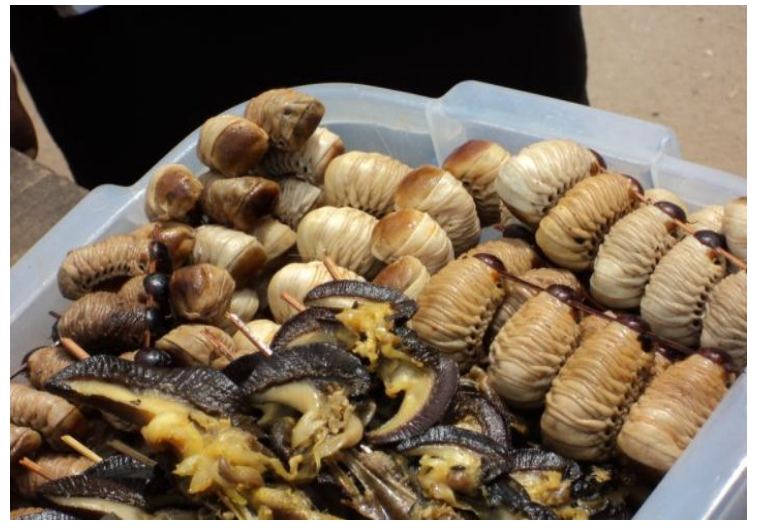


Plate 1. Freshly fried Rhynchophorus phoenicis displayed for sale alongside fried snails at Itokin market in Lagos State

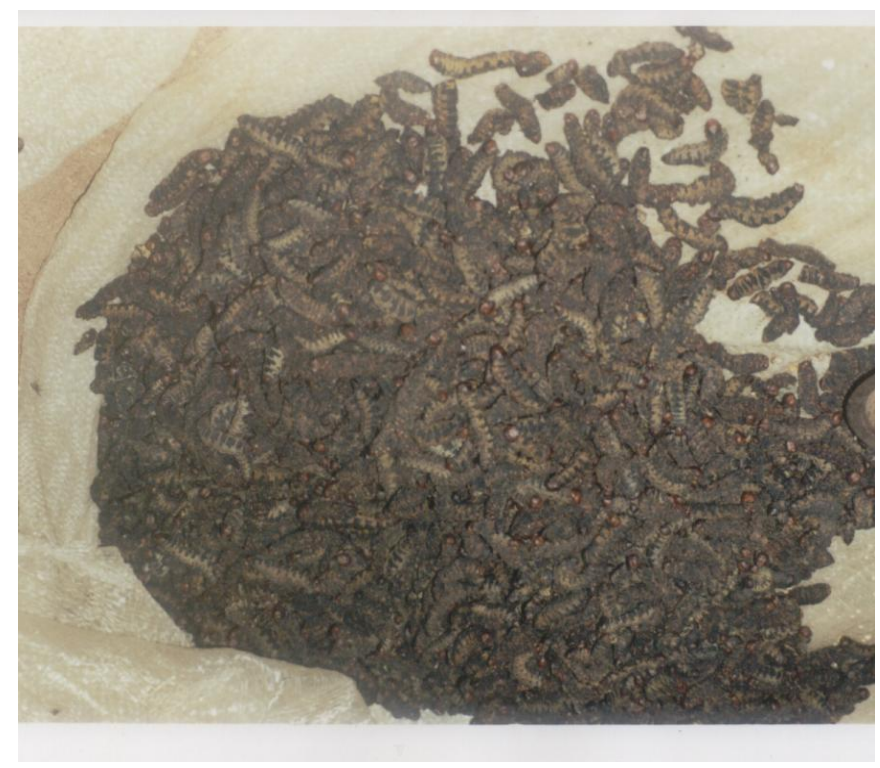

Plate 2. Dried Cirina forda larvae for sale at the market in Ekiti State

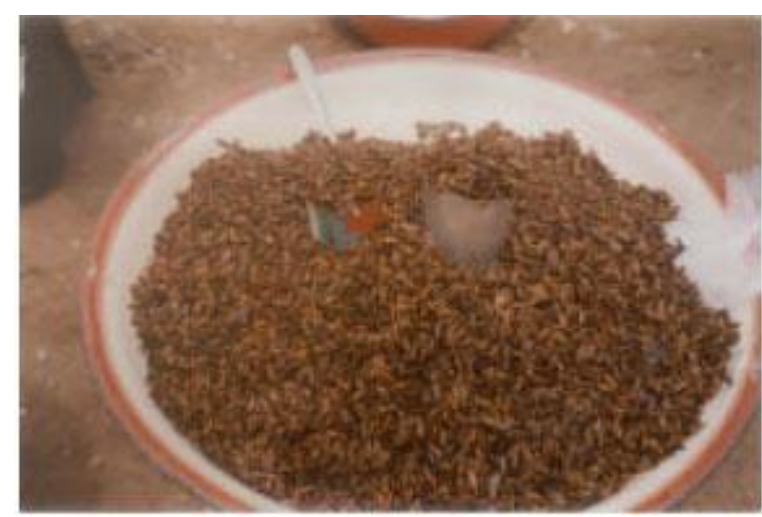

Plate 3. Dried alate form of Macrotermes natalensis (termites) on sale in Gboko main market, Benue State

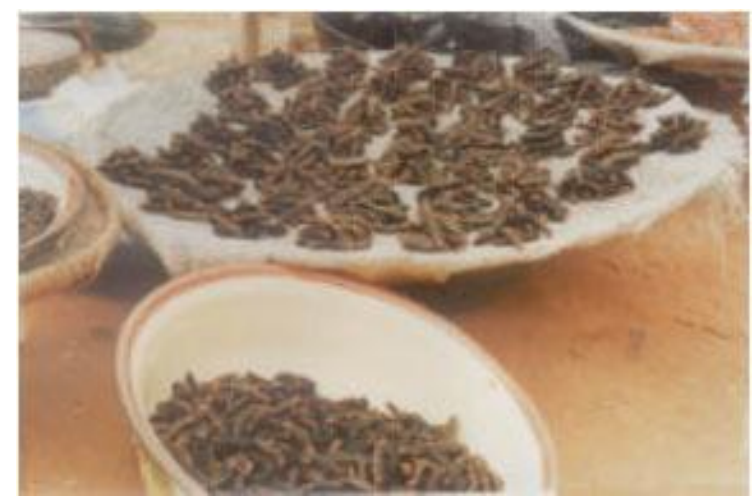

Plate 4: Dried Bunaea alcinoe larvae displayed for sale in Wurukum market in Makurdi, Benue State 


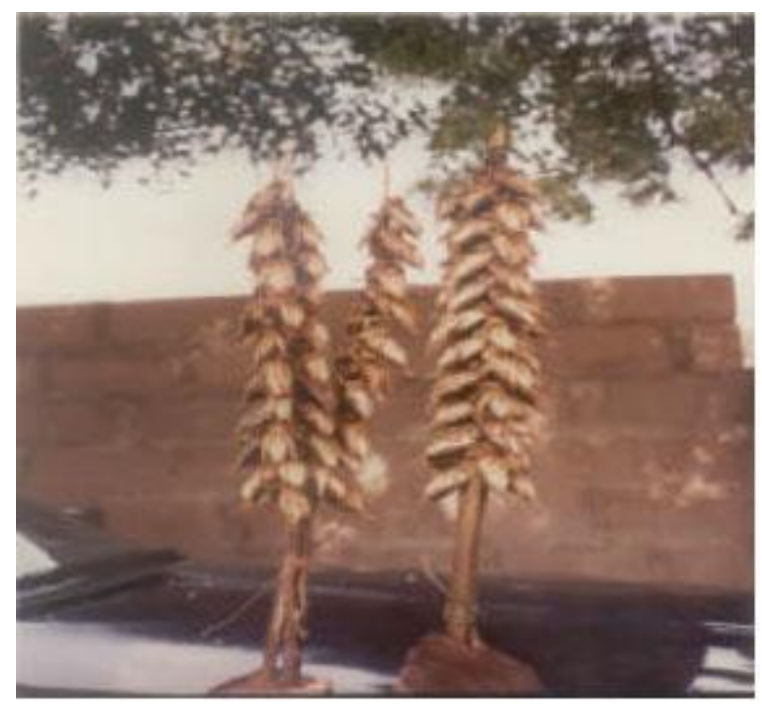

Plate5. Adults of Brachytrupes membranaceus (crickets) displayed on sticks for sale at Emere near Okaba in Benue State

\section{Potential for Expanding the Market}

Insects offer significant advantages in food production, especially when compared with traditional livestock production. There is considerable potential in widening the market for edible insects by incorporating insect protein in supplements, processed foods and animal feeds (Banjo et al., 2006). In addition, their trade, although seasonal, does provide additional income for rural as well as urban people especially women.

Although the market for edible forest insects is lucrative and growing, their collection, processing and marketing is mainly done in the rural areas while some sellers go to rural areas to purchase larvae for resale in cities at high prices (Adeduntan and Bada, 2004; Mbata and Chidumayo, 2003). More attention should be paid by entomologist to the biological potential of edible forest insects, including conservation, forest management, and development of artificial diet for domestication, agriculture, nutrition, and processing aspects.

The Federal as well as State governments should enforce the legislation against indiscriminate bush burning and illegal tree felling to preserve the habitats of these insects. Where necessary, Plantations of host plants should be established to promote large scale production of these edible insects. In instances where insects are traditional foods among a certain group, this fact can serve as a path to commercial development. Relevant commercial Nigerian edible forest insect species include the Rhynchophorus phoenicis (palm grub), Oryctes boas, Cirina forda, Anaphe venata, Bunaea alcinoe.

\subsection{Food Safety for Nigeria Edible Forest Insects}

Insects are traditional foods in many cultures and play an important role in human nutrition. The insect has been a good nutritional food source, especially for fat and protein. Future attempts to take advantage of this resource should include how to promote Nigeria edible forest insects as a nutritional food source. Information on the toxicity and food safety of insects is needed to satisfy consumer concerns. 
Studies by, Ashiru (1988) show Anaphe larvae among the insects that are an unusually good source of fat, having a calorific value of $6.113 \mathrm{kcal} / \mathrm{g}$. Unfortunately, these larvae have recently come under a shadow for possible involvement as the cause of a seasonal ataxic syndrome. In the absence of strong medical evidence, this insect is still widely consumed by both young and old.

In general, many insects are herbivorous and less problematic than omnivores. But pesticide use can make insects unsuitable for human consumption. Bioaccumulation of herbicides can occur in insects and this may pose a problem since edible plants have been consumed by the insects themselves. For example, in Akoko, Ondo State Nigeria, the grasshopper Cytacanthacris naeruginosus unicolor and Zonocerus variegatus are collected for sale as food, but its suitability as a safe food is controlled by possible contamination with organophosphorus pesticides.

\subsection{Future Trends}

Nigeria edible forest insects not only serve as a source of food from forest areas of Nigeria, but also reflect rich cultural traditions and a diverse biological resource. As these edible insects are good resources for generating income, there is likely to be an increase in the numbers of Nigeria edible insects collected. However, increases in demand could lead to competition and over exploitation. Forest fragmentation and habitat loss are increasing because of land development in the country. These trends may well lead to decreases in insect diversity as well as in populations of other native fauna and flora. Many Nigeria edible insect species are collected in the wild. The quantity collected and the species found depend on season and location.

Although, several entomologists are showing interest in entomophagy studies, in connection with the local people, studies should be conducted on the development of techniques for mass rearing on a commercial scale for several edible insect species. If such insects are to be used in a sustainable manner, appropriate commercial use depends on people's awareness of the insects' habitats and related factors. Furthermore, product development for adding value to edible insects is necessary.

\subsection{Constraint}

The problems with utilizing insects' proteins are the lack of social acceptance, nutritional knowledge, information and disbelief about delicacies of these insects that are naturally abundant in our farms and forests. There is need for insect eaters and entomologist to educate the public about the value of edible insects. There is also need for reduction in pesticide use by developing more efficient methods of harvesting pest species that are traditional foods such as grasshoppers.

\section{Conclusion}

This study further confirms the existence of entomophagy in Nigeria. Considering the economic, nutritional and ecological advantages of this traditional food source, its promotion deserves more attention both from national governments and assistance programmes. To manage insects in the interest of food security more attention should be given to 
environmentally sustainable harvesting methods. They should be made more available throughout the year by developing improved conservation methods or by farming this minilivestock.

In other words, most preferred edible insects, especially those with high nutritional content, can be reared or cultivated in the home gardens with the application of modern tools and techniques and sold to the people, who regard them as delicacies. In the long run, this may serve the twin purpose of insect (natural resource) use as food and conservation.

Finally, there is need for research on industrial scale mass-production of edible insects, for increased recognition of the nutritional and environmental importance of insects by national governments, and for increased involvement of the media and academia in dispelling unfounded cultural biases in the urban dwellers toward insects as food. Collecting these forest edible insects would not only protect their host plants but it could benefit the environment by reducing the need to use pesticides (DeFoliart, 2005).

\section{References}

Adeduntan, S. A., \& F. A. Bada. (2004). Socio-economic importance of local silkworm Anaphe venata to the rural dwellers in Ondo state, Nigeria. Proceedings of the 35th Annual Conference Entomologia Society Nigeria, Oct. 3-7, The Federal University of Akure, pp: 7-7.

Agbidye, F. S, Ofuya, T. I, \& Akindele, S. O. (2009). Marketability and Nutritional Qualities of Some Edible Forest Insects in Benue State, Nigeria. Pakistan Journal of Nutrition, 8, 917-922. http://dx.doi.org/10.3923/pjn.2009.917.922

Ajayi, O. E., \& C. O. Adedire (2007). Nutrient characteristics of the subterranean termite, Macrotermes subhyalinus (Rambur) (Isoptera: Termitidae). Nig. J. Entomol., 24, 42-47.

Ashiru, M. O., (1988). The food value of the larvae of Anaphe venata butler (Lepidoptera: Notodontidae). Ecol. Food Nutr., $22, \quad 313-320$. http://dx.doi.org/10.1080/03670244.1989.9991080

Banjo, A. D, Lawal,, O. A., \& Songonuga,, E. A (2006). The nutritional value of fourteen species of edible insects in southwestern Nigeria. African Journal of Biotechnology, 5(3), 298-301.

Capinera, John L (2004). Encyclopedia of Entomology. Kluwer Academic Publishing.

Chavunduka, D. M (1975). Insects as a source of food to the African. Rhodesia Science News. 9, 217-220.

De Foliart ,G. R (2002). The Human use of insects is a food resource: A Bibliographic Account in progress. http:// www.food- insects. Com/book.

De Foliart, G. (1992): Insects as human food. Crop Protection, 5(11), 395-399. http://dx.doi.org/10.1016/0261-2194(92)90020-6

DeFoliart, G. R (1989). The Human use of insects as food and animal feed. Bull Ent. Soc. Am., $35,22-35$. 


\section{Macrothink}

Journal of Biology and Life Science ISSN 2157-6076 2014, Vol. 5, No. 2

DeFoliart, G. R (1990). Insects as food in indigenous. Ethno-biology: implications and applications. Proceedings of $1^{\text {st }}$ International Conference on Ethno-biology. Belem, 1, 145-150.

DeFoliart, G. R (2005). Overview of role of edible insects in preserving biodiversity. In: Paoletti MG (ed) Ecological implications of minilivestock. Potential of insects, rodents, frogs and snails. Science Publishers, Inc., Enfield, 123-140

Ekop, E. A, Udoh, A. I., \& Akpan, P. E. (2010). Proximate and anti-nutrient compostion of four edible insects in Akwa Ibom State, Nigeria. World Journal of Applied Science and Technology, 2(2), 224-231.

FAO (1995): Non-wood forest products for rural income and sustainable forestry. Non-wood forest products 7. FAO. Rome.

Fasoranti J. O, \& Ajiboye D. O (1993). Some Edible Insects of Kwara State, Nigeria. Amer. Entomol. 39(2), 113-116.

Ifie, I., \& Emeruwa, C. H. (2011). Nutritional and anti-nutritional charactyeristics of larva of Oryctes monoceros. Agric. Biol. J. N. Am., 2(1), 42-46.

Malaisse, F. (1997). Se nourrir en forêt claire africaine. Approche écologique et nutritionnelle. Les Presses Agronomiques de Gembloux. Gembloux, Belgique.

Mbata, K. J., \& E. N. Chidumayo (2003). Traditional value of caterpillars (Insecta: Lepidoptera) among the bisa people of Zambia. Insect Sci. Applied, 23, 341-354.

Muyay T. (1981). Les Insects Comme Aliments de l'Homme. Pubn. Ser. II vol. 69. CEEB A. Bandundu, Zaire pp. 177.

Nkouka E. (1987). Les insectes comestibles dans les sociétés d'Afrique Centrale. Revue Scientifique et Culturelle du CICIBA, Muntu 6, 171-178.

Ramos-Elorduy, J. 2005). Insects: A hopeful food source. In: Ecological implications of minilivestock. Paoletti, M.G. Ed.; Science Pub. Enfield; 263-291.

Stack J, Dorward A, Gondo T, Frost P, Taylor F \& Kurebgaseka (2003). Mopane Worm Utilization and Rural Livelihoods in Southern Africa, CIFOR Livelihood Conference, Bonn.

\section{Copyright Disclaimer}

Copyright for this article is retained by the author(s), with first publication rights granted to the journal.

This is an open-access article distributed under the terms and conditions of the Creative Commons Attribution license (http://creativecommons.org/licenses/by/3.0/). 